\title{
Aplikasi Penjualan Sepatu Berbasis Web Pada PT. Metrox Global
}

\author{
Regita Tri Hastuti ${ }^{1}$, Ratih Yulia Hayuningtyas ${ }^{2}$ \\ ${ }^{1}$ Universitas Bina Sarana Informatika \\ e-mail: ${ }^{1}$ regitatri17@gmail.com \\ ${ }^{3}$ Universitas Nusa Mandiri \\ e-mail: ratih.ryl@nusamandiri.ac.id
}

\begin{tabular}{ccc}
\hline Diterima & Direvisi & Disetujui \\
$01-11-2021$ & $08-11-2021$ & $15-11-2021$ \\
\hline
\end{tabular}

\begin{abstract}
Abstrak - PT. Metrox Global merupakan perusahaan yang bergerak dibidang penjualan sepatu. Dalam menjalankan transaksi penjualan PT. Metrox Global masih menggunakan secara manual, dimana para customer datang langsung untuk melihat sepatu yang dicari dan untuk melihat kualitas bahan dari sepatu tersebut. Hal ini menyebabkan ketidakpuasaan customer terhadap pelayanan dan transaksi penjualan. Selain itu penjualan sepatu secara manual juga berdampak pada omset penjualan di PT. Metrox Global, dikarenakan pemasaran dan promosi mengenai produk tidak tersebar luas hanya mencakup area yang terbatas. Teknologi internet tentunya dapat dijadikan sebagai pemecahan masalah yang ada pada PT. Metrox Global, dengan cara membuat sistem informasi penjualan berbasis web. Jangkauan internet sangat luas sehingga dapat menyebarkan informasi mengenai produk yang ada keseluruh dunia, dapat diakses siapa saja serta dapat dilihat kapan saja. Dari permasalahan pada PT. Metrox Global semakin lama tidak efisien dan efektif sehingga dibutuhkan suatu aplikasi penjualan sepatu berbasis web yang dapat diakses dan lihat oleh siapa saja serta dapat dijadikan tempat promosi. Aplikasi penjualan sepatu berbasis web pada PT. Metrox Global dalam pembuatannya menerapkan Sytem Development Life Cycle (SDLC) yang memiliki lima tahapan dalam pembuatan aplikasi. Dengan adanya aplikasi penjualan sepatu berbasis web pada PT.Metrox Global dapat memberikan pelayanan yang baik bagi customer, informasi yang lengkap bagi customer serta dapat meningkatkan penjualan pada PT. Metrox Global melalui internet.
\end{abstract}

Kata Kunci: Penjualan, Aplikasi Penjualan, Website

\begin{abstract}
PT. Metrox Global is a company engaged in the sale of shoes. In carrying out sales transactions PT. Metrox Global still uses it manually, where customers come directly to see the shoes they are looking for and to see the quality of the materials of the shoes. This causes customer dissatisfaction with services and sales transactions. In addition, the sale of shoes manually also has an impact on sales turnover at PT. Metrox Global, because the marketing and a promotion of the product is not widespread, it only covers a limited area. an internet technology can certainly be used as a solution to existing problems at PT. Metrox Global, by creating a web-based sales information system. The reach of the internet is very wide so that it can spread information about existing products throughout the world, can be accessed by anyone and can be viewed at any time. From the problems at PT. Metrox Global is increasingly inefficient and effective so that a web-based shoe sales application is needed that can be accessed and viewed by anyone and can be used as a promotion place. Web-based shoe sales application at PT. Metrox Global in its manufacture applies the System Development Life Cycle (SDLC) which has five stages in making applications. With the application of web-based shoe sales at PT. Metrox Global can provide the goodservice for customers, complete information for customers and can increase sales at PT. Metrox Global via the internet.
\end{abstract}

Keywords: Sales, Sales Application, Website

\section{PENDAHULUAN}

Perkembangan informasi dengan adanya kemajuan teknologi mempengaruhi gaya hidup dan cara pandang masyarakat yang berada di lingkungan teknologi (Kardinal \& Tasrif, 2018). Teknologi informasi membuat manusia memilih cara yang tepat untuk memudahkan kegiatan dalam memenuhi kebutuhan (Imaniawan \& Elsa, 2017).
Teknologi Informasi banyak di manfaatkan oleh para pengusaha untuk meningkatkan usahanya. Salah satunya di dunia penjualan, sudah banyak sekali perusahaan yang bergerak di bidang penjualan dengan memanfaatkan teknologi informasi dalam menjalankan usahanya.

Internet merupakan suatu jaringan komunikasi global yang menghubungkan milyaran jaringan komputer secara terbuka (Payuda, Hermawan, 
Aldisetya, \& Yaddarabullah, 2020). Teknologi internet merupakan salah satu media informasi yang efektif dan efisiensi dalam penyebaran informasi yang dapat di akses oleh siapa saja, kapan saja dan dimana saja (Iriadi \& Indrasari, 2017). Salah satu manfaat internet tidak membutuhkan tempat, jarak dan waktu untuk melihat perkembangan bisnis (Kirlyana \& Rosyida, 2016) serta berguna bagi perusaahan di bidang penjualan, karena dengan adanya internet dapat membantu meningkatkan target penjualan yang memberikan keuntungan.

PT. Metrox Global adalah perusahaan yang bergerak dibidang penjualan yang menjual berbagai macam sepatu seperti flatshoes, dan sepatu sneakers. PT. Metrox Global masih menggunakan sistem manual dimana customer harus datang ke lokasi untuk membeli sepatu, selain itu pemasaran dan promosi produk hanya di area terbatas (Prasetyo \& Susanti, 2016). Jika hanya mengandalkan sistem penjualan saat ini akan berdampak terhadap kuantitas penjualan serta pendapatan perusahaan tidak mengalami peningkatan yang signifikan. Selain itu, belum tersedianya media pemasaran secara online membuat PT. Metrox Global kurang dikenal dan kurang kompetitif dalam dunia persaingan dengan toko sepatu lainnya.

Setiap perusahaan harus mengambil langkah yang cerdas dalam mengelola sistem kerjanya, salah satunya yaitu dengan e-commerce. E-commerce merupakan suatu transaksi perdagangan antara penjual dan pembeli melalui media internet (Veza, 2019). PT. Metrox Global memanfaatkan internet untuk mengatasi permasalahan yang ada, dengan membuat sistem informasi penjualan berbasis web menggunakan Sytem Development Life Cycle (SDLC).

SDLC merupakan metode pengembangan sistem tradisional yang paling banyak digunakan oleh organisasi saat ini (Purba, Hery, \& Widjaja, 2020). Metode pengembangan software SDLC (System Development Life Cycle) ini terdiri dari 5 tahapan (Sukamto \& Shalahuddin, 2018) yaitu analisis kebutuhan, desain, pembuatan kode program, pengujian, pendukung atau pemeliharaan.

Analisis kebutuhan sistem pada aplikasi penjualan berbasis web digambarkan dengan usecase diagram. Menurut (Sukamto \& Shalahuddin, 2018) Use case diagram merupakan pemodelan untuk kelakuan (behavior) sistem informasi yang akan dibuat. Sebuah interaksi antara satu atau lebih aktor dengan sistem informasi yang dibuat ini sebagai deskripsi Use case (Alkhalfan et al., 2020).

Pada tahapan desain mengubah kebutuhan menjadi bentuk yang mudah dimengerti perangkat lunak (Durachman, 2009) seperti class diagram. Class diagram menggambarkan logika hubungan antara kelas objek dan kelas serta membatasi hubungan antar objek yang menyediakan fungsi operasi (Sutanto, 2020).
Kemudian akan dibuatkan kode program menggunakan bahasa pemrograman html, php, dan mysql. Pengujian, pendukung dan pemilahraan penting bagi sebuah aplikasi, dimana pengujian digunakan untuk mengetahui kesalahan yang ada, sedangkan pendukung dan pemeliharaan untuk menjaga aplikasi ini dapat berjalan dengan baik.

Aplikasi penjualan sepatu berbasis web pada PT.Metrox Global dapat memberikan pelayanan yang baik bagi customer, informasi yang lengkap bagi customer serta dapat meningkatkan penjualan pada PT. Metrox Global melalui internet sehingga dapat mengatasi permasalahan yang ada pada PT. Metrox Global.

\section{METODE PENELITIAN} yaitu:

Metode yang digunakan pada penelitian ini

a. Metode Pengumpulan Data

Pada metode pengumpulan data ini menggunakan:

Observasi

Datang langsung ke PT. Metrox Global untuk melihat dan menganalisa permasalahan yang ada.

\section{Wawancara}

Melakukan tanya jawab terhadap bagian terkait penjualan untuk mengetahui proses penjualan yang ada di PT. Metrox Global.

\section{Studi Pustaka}

Mengumpulkan dan mencari literatur tentang aplikasi penjualan berbasiswa web untuk membangun sebuah aplikasi di PT. Metox Global.

\section{b. Metode Pengembangan Software}

Pada Metode pengembangan sotfware menggunakan SDLC (System Development Life Cycle) yang terdiri dari lima tahapan.

\section{Analisis Kebutuhan}

Menganalisa kebutuhan yang digunakan dalam pembuatan aplikasi penjualan sepatu pada PT. Metrox Global dimulai dari analisis kebutuhan software dan analisa kebutuhan pengguna.

\section{Desain}

Merepresentasikan analisis kebutuhan kedalam bentuk activity diagram, usecase diagaram dan class diagram.

\section{Pembuatan Kode Program}

Pembuatan kode program menggunakan bahasa pemrograman html, sql, dan php. Pada tahapan ini membuat form-form yang akan digunakan oleh pengguna aplikasi penjualan berbasis web.

\section{Pengujian}

Pengujian menggunakan blackbox testing untuk meminimalisir kesalahan (error) dan memastikan apakah website yang dibuat sesuai dengan yang diinginkan atau tidak.

\section{Pendukung dan Pemeliharaan}

Pada tahapan ini dapat mengulangi proses pengembangan mulai dari analisis spesifikasi 
untuk perubahan perangkat lunak yang sudah ada, tetapi tidak untuk membuat perangkat lunak baru.

\section{HASIL DAN PEMBAHASAN}

\section{A. Tinjauan Kasus}

\section{Proses Bisnis Sistem Berjalan}

Proses bisnis sistem berjalan yang ada di PT Metrox Global yaitu:

a. Proses pertama, penjualan barang diawali dengan customer datang langsung dan melihat produk yang ingin dibeli, lalu staff toko melayani customer yang datang ke toko. Jika customer sudah selesai memilih dan mendapatkan produk yang ingin dibeli lalu produk dibawa staff untuk transaksi dikasir.

b. Proses kedua, setelah itu dilanjutkan proses pembayaran tunai dengan penerimaan barang yang sudah dibeli oleh customer, lalu kasir menulis di bon jumlah sepatu beserta harga dan total harga yang dibeli customer.

c. Proses ketiga, membuat laporan penjualan yang dibuat setiap hari, kasir merekap dan menghitung hasil penjualan harian dan melaporkannya ke area manager.

\section{Activity Diagram Sistem Berjalan}

Menggambarkan aktivitas dari sebuah sistem menggunakan activity diagram. Berikut adalah activity diagram sistem berjalan yang ada pada PT. Metrox Global dapat dilihat pada gambar dibawah ini.

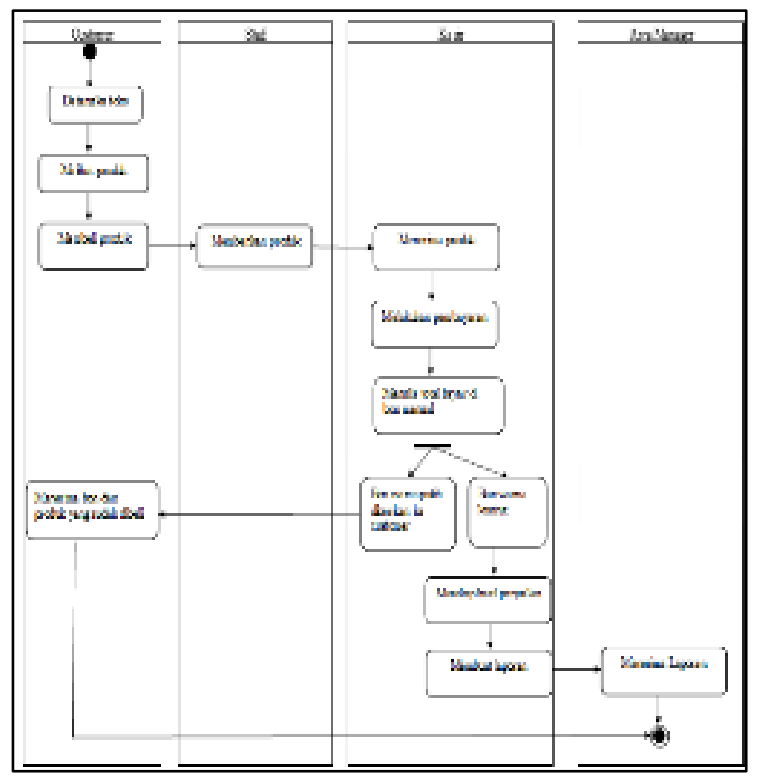

Sumber: (Hastuti \& Hayuningtyas, 2021)

Gambar 1. Activity Diagram Sistem Berjalan

\section{B. Analisis Kebutuhan}

1. Analisis Kebutuhan Pengguna

a. Analisis Kebutuhan Admin

1) Admin dapat melakukan login

2) Admin dapat mengelola data admin

3) Admin dapat mengelola data produk

4) Admin dapat mengelola data biaya kirim

5) Admin dapat mengelola informasi tentang website

6) Admin dapat mengelola data anggota

7) Admin dapat mengubah status konfirmasi pembayaran

8) Admin dapat mengelola detail data order dan laporan penjualan

9) Admin dapat melakukan logout

b. Analisis Kebutuhan Pengunjung

1) Pengunjung dapat mendaftar menjadi anggota.

2) Pengunjung dapat melihat produk dan detail produk di konten beranda dan kategori produk.

3) Pengunjung dapat membaca informasi cara pembelian dan tentang kami.

c. Analisis Kebutuhan Anggota

1) Anggota dapat login.

2) Anggota dapat melihat produk dan detail produk dikonten beranda dan kategori.

3) Anggota dapat membaca konten cara pembelian dan tentang kami.

4) Anggota dapat melakukan pemesanan produk.

5) Anggota dapat melakukan konfirmasi pembayaran.

6) Anggota dapat mengisi form testimonial pada halaman pengunjung.

7) Anggota dapat melakukan logout.

\section{Analisis Kebutuhan Sistem}

\section{a. Sistem Admin}

Untuk menjalankan aplikasi penjualan admin harus login terlebih dahulu. Setelah admin berhasil login, selanjutnya admin akan masuk ke halaman beranda admin dan terdapat menu-menu yang tersedia untuk mengatur data-data informasi yang muncul di website, dan dapat melihat order pembelian masuk dan detail transaksi yang dihasilkan.

\section{b. Sistem Anggota}

Anggota harus login dengan email dan password yang dimilikinya, jika belum menjadi anggota pengunjung dapat mendaftar menjadi anggota. Setelah itu anggota akan masuk ke halaman user yang berisi tampilan beranda dan tampilan semua produk. Setelah itu anggota akan masuk ke halaman user pesanan, pembelian, produk hingga transaksi melalui keranjang belanja dan mengakses semua konten yang tersedia.

Berikut adalah gambaran use case diagram dari analisa kebutuhan pada penelitian ini. 


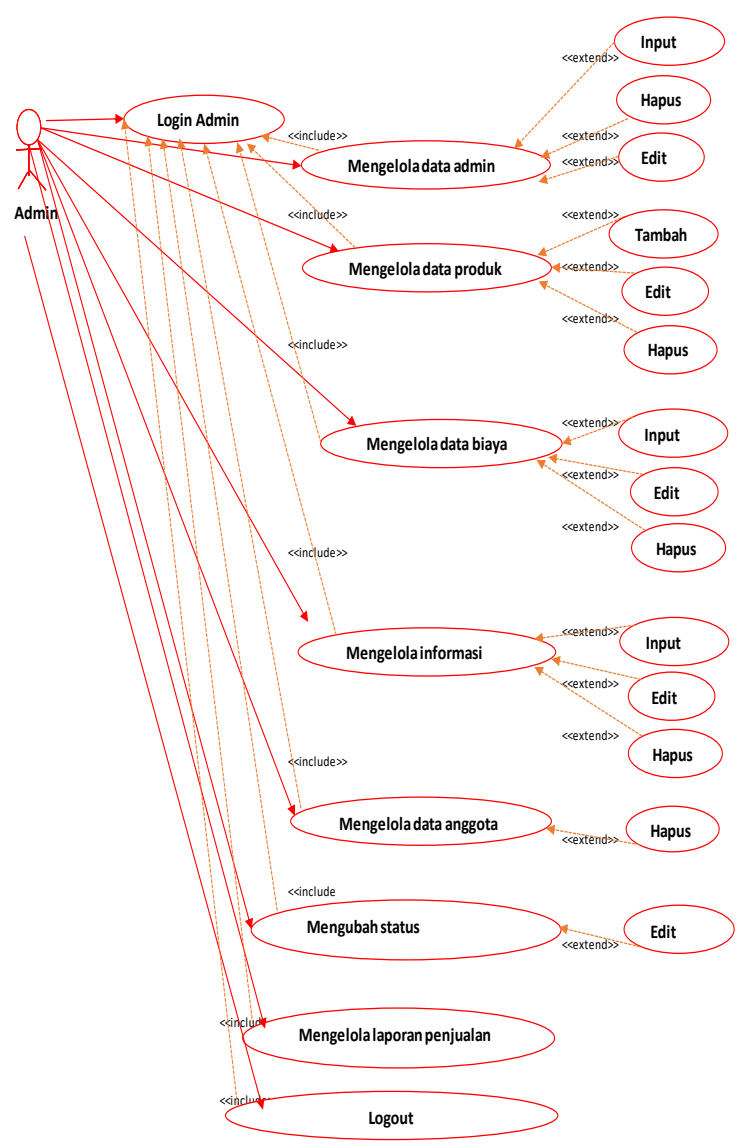

Sumber: (Hastuti \& Hayuningtyas, 2021)

Gambar 2. Use Case Diagram Admin Hasil Penelitian

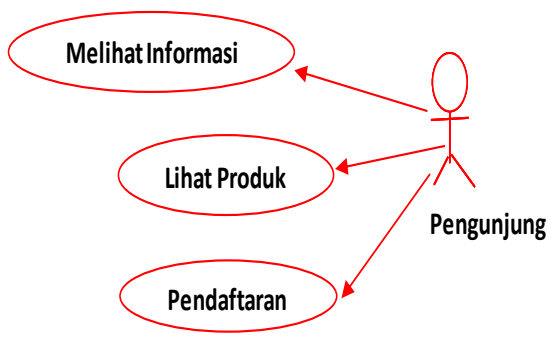

Sumber: (Hastuti \& Hayuningtyas, 2021)

Gambar 3. Use Case Diagram Pengunjung Hasil Penelitian

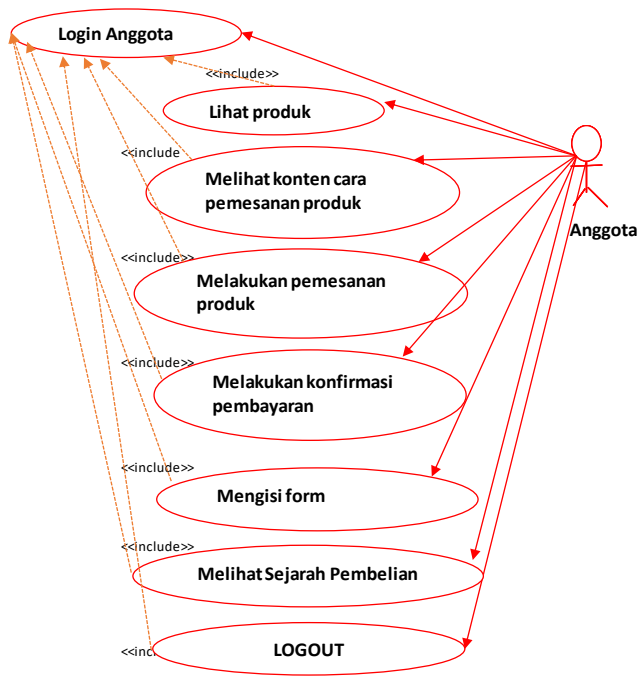

Sumber: (Hastuti \& Hayuningtyas, 2021)

Gambar 4. Use Case Diagram Anggota Hasil Penelitian

\section{Class Diagram}

Di dalam class diagram terdapat tiga bagia yaitu diagram kelas, nama dan operasi. Berikut adalah gambar class diagram pada penelitian ini.
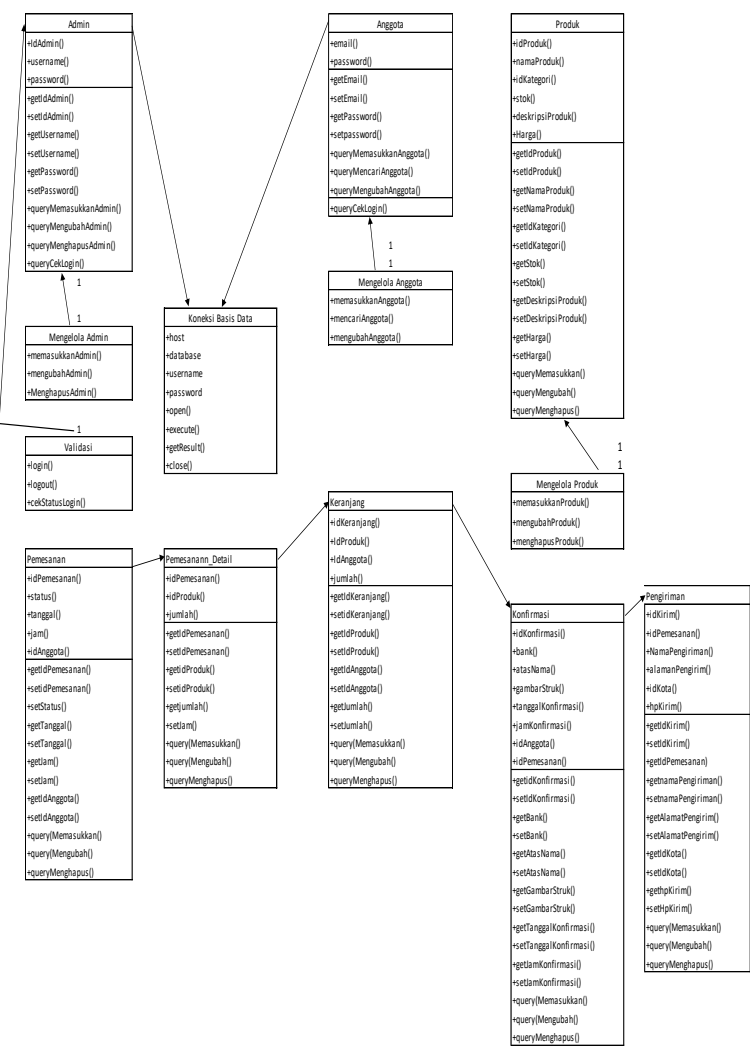

Sumber: (Hastuti \& Hayuningtyas, 2021)

Gambar 5. Class Diagram Hasil Penelitian 


\section{Implementasi}

Implementasi dari penelitian ini dapat dilihat pada gambar berikut ini:

\section{a. Halaman Login}

Halaman login digunakan untuk masuk kedalam aplikasi penjualan berbasis web pada PT. Metrox Global bagi admin dan anggota. Dengan cara mengisikan user dan password, dan akan masuk ke dalam beranda masing-masing pengguna. Berikut adalah tampilan dari halaman login.

\section{The Little Things She Needs}

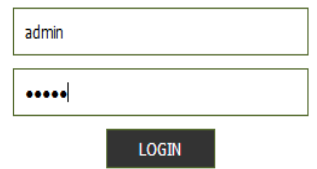

Sumber: (Hastuti \& Hayuningtyas, 2021)

Gambar 6. Halaman Login Hasil Peneltiian

\section{b. Halaman Pengunjung}

Halaman pengunjung hanya dapat melihat produk-produk sepatu yang dijual, informasi mengenai PT. Metrox Global, testimoni dari pembeli kemudian informasi terkait cara pembayaran. Berikut adalah tampilan dari halaman pengunjung.

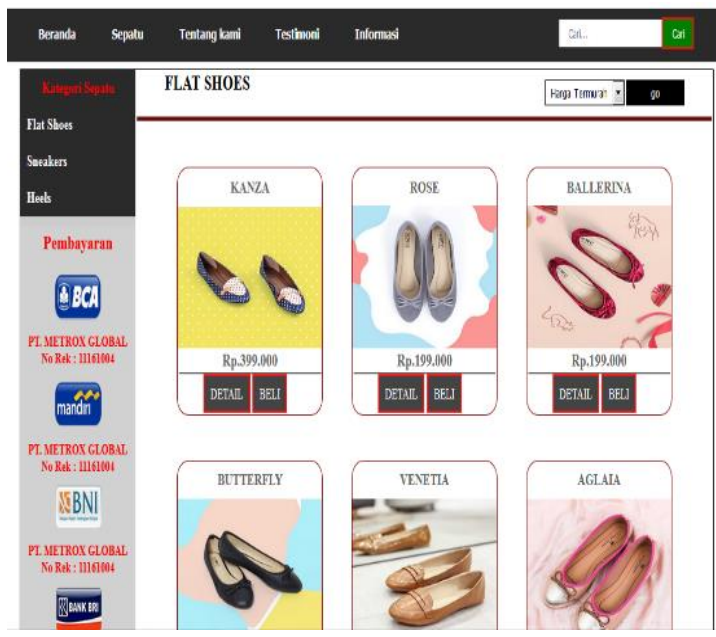

Sumber: (Hastuti \& Hayuningtyas, 2021)

Gambar 7. Halaman Pengunjung Hasil Penelitian

\section{c. Halaman Menu Keranjang}

Halaman keranjang belanja berisikan produkproduk yang dibeli oleh anggota, tentunya harus melakukan login terlebih dahulu. Kemudian dapat membeli sepatu lebih dari satu produk yang nantinya akan masuk kedalam keranjang belanja dan menampilkan total dari pembelajaan. Berikut adalah tampilan dari halaman keranjang.

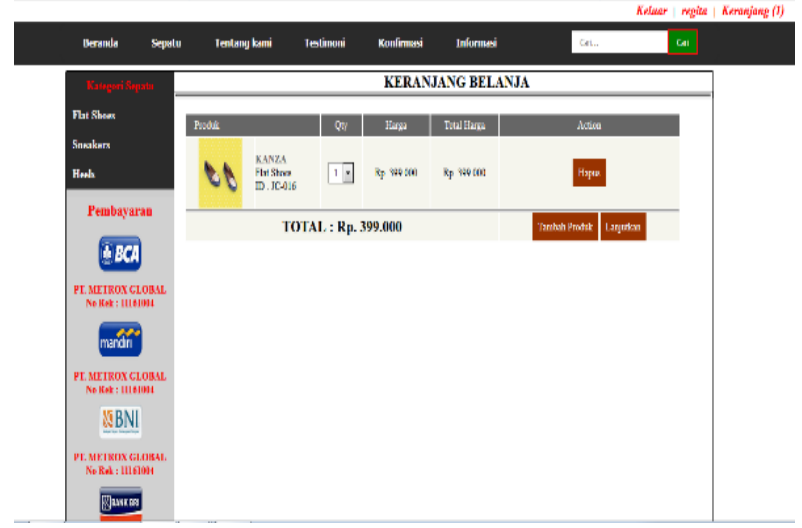

Sumber: (Hastuti \& Hayuningtyas, 2021)

Gambar 8. Halaman Menu Keranjang Hasil Penelitian

\section{Pengujian}

Pengujian pada penelitian menggunakan Blackbox testing. Berikut adalah pengujian yang dilakukan pada penelitian ini.

Tabel 1. Hasil Pengujian Black Box Testing Halaman Login Anggota Hasil Penelitian

\begin{tabular}{|c|c|c|c|c|c|}
\hline No & $\begin{array}{c}\text { Skanari } \\
\text { o } \\
\text { Penguji }\end{array}$ & $\begin{array}{l}\text { Test } \\
\text { Case }\end{array}$ & $\begin{array}{c}\text { Hasil } \\
\text { Yang } \\
\text { Dihara } \\
\text { pkan }\end{array}$ & $\begin{array}{c}\text { Sesuai } \\
\text { Harap } \\
\text { an }\end{array}$ & $\begin{array}{c}\text { Kesi } \\
\text { mpul } \\
\text { an }\end{array}$ \\
\hline 1 & $\begin{array}{l}\text { Userna } \\
\text { me dan } \\
\text { Passwo } \\
\text { rd tidak } \\
\text { diisi } \\
\text { kemudi } \\
\text { an klik } \\
\text { tombol } \\
\text { login }\end{array}$ & $\begin{array}{l}\text { Userna } \\
\text { me: } \\
\text { (koson } \\
\text { g) } \\
\text { Passw } \\
\text { ord } \\
\text { (koson } \\
\text { g) }\end{array}$ & $\begin{array}{l}\text { Sistem } \\
\text { akan } \\
\text { menola } \\
\mathrm{k} \text { akses } \\
\text { user dan }\end{array}$ & $\begin{array}{l}\text { Sesuai } \\
\text { harapa } \\
n\end{array}$ & Valid \\
\hline 2 & $\begin{array}{l}\text { Memas } \\
\text { ukkan } \\
\text { Userna } \\
\text { me dan } \\
\text { mengos } \\
\text { ongkan } \\
\text { Passwo } \\
\text { rd } \\
\text { kemudi } \\
\text { an klik } \\
\text { tombol } \\
\text { login }\end{array}$ & 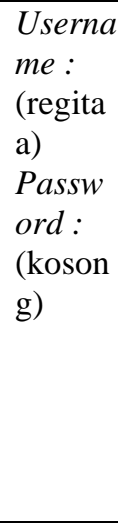 & $\begin{array}{l}\text { Sistem } \\
\text { akan } \\
\text { menola } \\
\mathrm{k} \text { akses } \\
\text { user dan } \\
\text { tampil } \\
\text { keteran } \\
\text { gan "Isi } \\
\text { isian } \\
\text { ini" di } \\
\text { kolom } \\
\text { Passwo } \\
\text { rd. }\end{array}$ & $\begin{array}{l}\text { Sesuai } \\
\text { harapa } \\
n\end{array}$ & Valid \\
\hline 3 & $\begin{array}{l}\text { Userna } \\
\text { me tidak } \\
\text { diisi dan } \\
\text { Passwo } \\
r d \text { diisi } \\
\text { tombol } \\
\text { login }\end{array}$ & 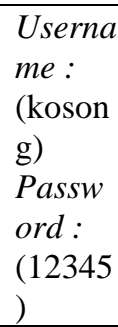 & $\begin{array}{l}\text { Sistem } \\
\text { akan } \\
\text { menola } \\
\mathrm{k} \text { akses } \\
\text { user dan } \\
\text { menam } \\
\text { pilkan } \\
\text { keteran }\end{array}$ & $\begin{array}{l}\text { Sesuai } \\
\text { harapa } \\
n\end{array}$ & Valid \\
\hline
\end{tabular}




\begin{tabular}{|c|c|c|c|c|c|}
\hline & & & $\begin{array}{l}\text { gan } \\
\text { Isikanus } \\
\text { ername }\end{array}$ & & \\
\hline 4 & $\begin{array}{l}\text { Mengeti } \\
\text { kkan } \\
\text { salah } \\
\text { satu } \\
\text { kondisi } \\
\text { salah } \\
\text { pada } \\
\text { Userna } \\
\text { me atau } \\
\text { Passwo } \\
\text { rd } \\
\text { kemudi } \\
\text { an klik } \\
\text { tombol } \\
\text { login }\end{array}$ & $\begin{array}{l}\text { Userna } \\
\text { me : } \\
\text { regitaa } \\
\text { (benar) } \\
\text { Passw } \\
\text { ord: } \\
\text { abcd } \\
\text { (salah) }\end{array}$ & $\begin{array}{l}\text { Sistem } \\
\text { akan } \\
\text { menola } \\
\text { k akses } \\
\text { user dan } \\
\text { menam } \\
\text { pilkan } \\
\text { "Userna } \\
\text { me Dan } \\
\text { Passwo } \\
\text { rd anda } \\
\text { salah" } \\
\text { kolom } \\
\text { userna } \\
\text { me dan } \\
\text { passwor } \\
\text { dkemba } \\
\text { li } \\
\text { kosong }\end{array}$ & $\begin{array}{l}\text { Sesuai } \\
\text { harapa } \\
n\end{array}$ & Valid \\
\hline 5 & $\begin{array}{l}\text { Mengeti } \\
\text { kkan } \\
\text { Userna } \\
\text { me dan } \\
\text { Passwo } \\
\text { rd } \\
\text { dengan } \\
\text { data } \\
\text { yang } \\
\text { benar } \\
\text { kemudi } \\
\text { an klik } \\
\text { tombol } \\
\text { login }\end{array}$ & $\begin{array}{l}\text { Userna } \\
\text { me : } \\
\text { regitaa } \\
\text { (benar) } \\
\text { Passw } \\
\text { ord: } \\
12345 \\
\text { (benar) }\end{array}$ & $\begin{array}{l}\text { Sistem } \\
\text { meneri } \\
\text { ma } \\
\text { akses } \\
\text { login } \\
\text { dan } \\
\text { kemudi } \\
\text { an } \\
\text { langsun } \\
\text { g } \\
\text { menam } \\
\text { pilkan } \\
\text { menu } \\
\text { utama }\end{array}$ & $\begin{array}{l}\text { Sesuai } \\
\text { harapa } \\
n\end{array}$ & Valid \\
\hline
\end{tabular}

\section{KESIMPULAN}

Aplikasi penjualan sepatu berbasis web pada PT. Metrox Global tentunya dapat dijadikan solusi dari pemasalahan yang ada. Dengan adanya aplikasi ini sangat membantu PT. Metrox Global untuk mempromosikan produknya menjadi lebih luas, dapat meningkatkan kualitas pelayanan pada customer, penjualan menggunakan media internet sehingga dapat di akses kapan saja dan dimana saja serta meningkatkan daya saing usaha.

Selain itu aplikasi penjualan sepatu berbasis web Pada PT. Metrox Global, digunakan sebagai media penyimpanan dan pengelolaan data transaksi penjualan bagi pemilik agar lebih efisien dan efektif dalam pengembangan usahanya.

\section{REFERENSI}

Alkhalfan, A. S., Altheeb, Z. W., Alshamsi, N. A., Alothman, H. W., Almarashdeh, I., Alshabanah, M., ... Alsmadi, M. K. (2020). Designing and Developing of E-Commerce
Website for Unused New Goods Shopping. International Journal of Scientific Research in Science and Technology, 7(2), 215-225. https://doi.org/10.32628/ijsrst207233

Durachman, Y. (2009). Pengembangan Sistem Informasi Akademik Berbasis Web (Studi Kasus: SMA Muhammadiyah 7 Sawangan Depok). Studia Informatika: Jurnal Sistem Informasi, 2(1), 51-56.

Hastuti, R. T., \& Hayuningtyas, R. Y. (2021). Aplikasi Penjualan Sepatu Berbasis Web Pada PT. Metrox Global. Bekasi.

Imaniawan, F. F. D., \& Elsa, U. M. (2017). Sistem Informasi Penjualan Sepatu Berbasis Web Pada Vegas Hyper Purwokerto. IJSE - Indonesian Journal on Software Engineering, 3(2), 82-91.

Iriadi, N., \& Indrasari, A. U. (2017). Sistem Informasi Penjualan Berbasis Web Pada CV . Bambu Jaya Jakarta. Speed.Web.Id, 9(3), 34-39. Retrieved from

http://speed.web.id/ejournal/index.php/speed/a rticle/view/337/330

Kardinal, \& Tasrif, E. (2018). Perancangan Sistem ECommerce Pada Toko Salsa Sport Berbasis Web. Voteteknika (Vocational Teknik Elektronika Dan Informatika), 6(2), 37. https://doi.org/10.24036/voteteknika.v6i2.101 985

Kirlyana, B., \& Rosyida, S. (2016). Sistem Informasi Penjualan Sepatu Handmade Berbasis Web. Information Management for Educators and Professionals, 1(1), 22-31.

Payuda, M. F., Hermawan, E., Aldisetya, M., \& Yaddarabullah. (2020). Rancang Bangun Sistem Informasi Penjualan Pada Pt. Duta Perfume Berbasis Web Menggunakan Metode Sekuensial Linier. Jurnal Algoritma, Logika Dan Komputasi, 3(1), 229-237. https://doi.org/10.31219/osf.io/gd526

Prasetyo, A., \& Susanti, R. (2016). Sistem Informasi Penjualan Berbasis Web Pada PT. Cahaya Sejahtera Sentosa Blitar. Jurnal Ilmiah Teknologi Informasia Asia, 10(2), 1-16.

Purba, J. T., Hery, \& Widjaja, A. E. (2020). Ecommerce Implementation in Supporting Business Services Strategy (Case Study at Petshop Gifaro Evidence). Journal of Physics: Conference Series, 1563(1).

Sukamto, R. A., \& Shalahuddin, M. (2018). Rekayasa Perangkat Lunak. Bandung: Informatika Bandung.

Sutanto, P. H. (2020). Ecommerce Design Based Multi Vendor Case Study PT. Mutiara Katalog Indonesia. Mantik, 3(4), 444-450.

Veza, O. (2019). Perancangan E-commerce Untuk Memperluas Produk Komunikasi di PT. Golden Communication Berbasis Web Mobile. Jurnal Teknik Ibnu Sina (JT-IBSI), 4(1), 95-100. https://doi.org/10.36352/jt-ibsi.v4i1.180. 